\title{
Executive Director's Report
}

\author{
Catherine E. Rudder, American Political Science Association
}

Directing this cooperative society continues to be an exhilarating, rewarding experience, though the pace of change can be disconcerting. The sources underlying APSA's increasingly rapid evolution are several: new technical possibilities in worldwide communication, changes in the academic and funding environment, generational shifts, and an evergrowing awareness of the discipline's societal responsibilities. These changes are accompanied by the fervent desire of APSA's officers, volunteers, and staff to create an organization that responds to and anticipates the individual and collective needs of members and all political scientists.

\section{Collapse of Time and Space}

The accumulation of individual decisions produces policy. APSA purchased its first computer in 1984. By 1999, the Association has a computer on every desk and has wholeheartedly embraced the opportunities digital technologies offer for surmounting the barriers that time and space used to present to scholarly communication. President Matthew Holden, our Council, APSA's committees, and the national staff are working together to acquire, develop, and employ digital means to accomplish our goals. Previous Councils and committees have been consciously constructing this policy for a number of years, as you know if you have followed my previous reports and others appearing in PS.

You may, however, be surprised by the significant changes that seem to have occurred at APSA all at once, changes that require flexibility and new ways of interacting with each other. You have no doubt visited APSA's increasingly comprehensive web site, used the fully searchable online Annual Meeting Program (available weeks before the paper version), browsed the online collection of Annual Meeting papers, and enjoyed faster communica- tions with APSA staff via email. What may startle you, however, is the degree to which APSA programs are increasingly taking advantage of and relying on digital technology.

\section{Timeliness}

Doing things digitally means we can deliver information to members in a most timely fashion. With $P S$ and the Personnel Services Newsletter moving to the web (PSonline and PSNonline, of course), members can learn of professional opportunities like fellowships, prize competitions, nonfaculty jobs, and conferences in time to compete for or participate in them. Not being tied to a paper production and mailing schedule is especially important for $P S N$, because many positions require a fast turn around and can only be listed usefully online. Similarly, many of the opportunities that would not have been listed in the quarterly issues of $P S$ because of space constraints or short deadlines can now be found on PSonline.

One question facing various APSA committees is when to alert members that new information has been placed on the web. Right now, we are erring on the side of not emailing members regularly about new web listings, but I fear that many members miss opportunities as a result of our reticence and reluctance to add to their already full email boxes. If you would like to be alerted when substantial changes are made on our web site, please let me know, and we will add you to the notification list.

\section{Solving Problems}

The ability to make virtual connections is helping APSA solve difficult problems such as processing Annual Meeting paper proposals. The 50 members of the Program Committee now handle as many as 6,000 proposals each year, most of which are submitted for consider- ation by more than one division head. The sheer volume of transactions has made the work of the Program Committee extraordinarily difficult, time-consuming, and frustrating. APSA members submitting proposals also expressed some dissatisfaction with the proposal process when responding to a survey we conducted last year.

Two years ago we instituted central processing of proposals: members submit proposals to the national office, where they are cataloged, classified, and forwarded to the appropriate members of the Program Committee. Proposals could be submitted via the web, email, and snail mail. This year, the standing Committee on the Annual Meeting, led by Peter Lange of Duke University, reviewed the entire proposal system and recommended to the Council that we invest in the necessary technology and move to an entirely web-based, paperless procedure. This proposal was ratified by the Council. Beginning this fall, the Program Committee will review proposals via the web and will communicate their decisions to accept or reject proposals electronically.

In a similar vein, the Departmental Services Committee has determined that the most efficient, flexible way to collect data for the upcoming, once-a-decade Biographical Directory is to let members enter their own information, exactly as they would like it to appear, via the web. Members can check and update their entries until the closing date next year-a process more timely and responsive to members' needs than in the past. In this case, we will be offering both a print and a searchable CD-ROM version of the new publication when it appears in 2000. A parallel decision concerning submissions was made with regard to the Personnel Service Newsletter. Only web submissions can now be accepted. As a result of this technology, we are able to offer subscrip- 
tions to PSNonline at half the paper price to U.S. members and one-third the price to international members.

\section{Reducing Costs?}

Concerns for efficiency, timeliness, and accuracy necessitated these decisions. Oftentimes, however, costs are not reduced (or at least not yet) by going digital. In "Comparing Electronic Journals to Print Journals," Janet Fisher, associate director of journals publishing at MIT Press, concluded that while production of an electronic journal costs substantially less than a print one she examined, the overhead costs for the electronic journal in her study were a remarkable $1,240 \%$ higher. This difference resulted in part from the comparatively reduced content of the electronic journal she examined and "the conservatism of the author community." Fisher clearly implied that this overhead obstacle, while formidable, is temporary and will be overcome. (The full report appears in Technology and Scholarly Communication, ed. Richard Ekman and Richard E. Quandt [University of California Press, 1999].)

In the meantime, however, those of us who must make cost-effective decisions find ourselves in a bind between the need to take advantage of the new technology and to move prudently in concert with members' ability and willingness to use it. Operating simultaneously in paper and electronic forms is not always a viable choice financially or organizationally. Of some help is the fact that those who prefer to deal with paper can simply print their own copies.

\section{Worldwide Access}

Once one gets past the hurdle of learning to use the web, as most members already have, the advantages of this technology are considerable and multiplied many times the further a member lives from the U.S. The web has opened to APSA literally a world of possibilities unimaginable in the past. For example,
APSA's Civic Education Network and web page serve an international audience and constitute a significant element of APSA's International Civic Education Project. APSA's new joint venture with the European Consortium for Political Research-a job exchange clearinghouse - is only feasible because of the web. Another electronic project, instituted in June, offers members access to the entire online archive of the American Political Science Review, a special boon to international members and others who do not have access to JSTOR, a digital archive of 100 scholarly journals including the APSR.

\section{Facilitating Job Placement}

In another development, the Annual Meeting Placement Service went online in June with listings of employers and those looking for employment. Of course, the Placement Service will also be conducted in the old fashioned, in-person way at the meeting itself. The online listings are being offered as a benefit to job seekers, domestic and international, allowing them to familiarize themselves with available jobs prior to the meeting. Similarly, employers can now review the credentials of applicants in the serenity of their offices and arrange meetings prior to the conference. Because participants can prepare well ahead of going to Atlanta, the Placement Service should lose much of its "meat-market" atmosphere. Our hope next year is to integrate the Placement Service, called E-jobs on our web site, with the online Personnel Service Newsletter and to create a yearround, virtual placement service.

Also, the bulletin boards that members use to leave messages for colleagues at the Annual Meeting will be replaced by an electronic message service. And for the second

\section{Digital Projects at APSA*}

APSANet, APSA's Web Site <www.apsanet.org >

PSonline <www.apsanet.org/PS>

PSNonline <www.apsanet.org/PSN>

E-Jobs <www.apsanet.org/jobs>

APSA-ECPR Scholar Clearinghouse <www.apsanet.org/exchange>

Centennial Biographical Directory < search.apsanet.org >

Annual Meeting Proposal System <www.apsanet.org $/ \mathrm{mtgs} / 2000 \mathrm{call} />$

Civic Education Network and Web Page <www.apsanet.org/CENnet/>

Education Web Page, Contributing Editor, Stephen Bennett

$<w w w . a p s a n e t . o r g /$ teach $/>$

Washington Insider < www.apsanet.org/PS/washington/>

Professional Opportunities Web Page <www.apsanet.org/opps/>

JSTOR, 100 Electronic Journals Online <www.jstor.org >

PROceedings, Annual Meeting Papers Online <PRO. Harvard.edu>

Numerous Listservs of Organized Sections, Committees, and Task Forces

$<w w w$.apsanet.org/about/>

Online Ordering of Publications and Membership <www.apsanet.org/pubs/>

and <www.apsanet.org/about>

Free Online Availability of Numerous APSA Materials

Governance by Email

Cyber Stop and Electronic Message Service at the Annual Meeting

Online newsletters of Organized Sections <www.apsanet.org/about/ sections/>

Special projects of Organized Sections such as "The Working Papers of Political Methodology" < polmeth.calpoly.edu/papers.html> and the "Law and Courts Book Reviews" <www.unt.edu/lpbr/>

* For a full listing of the innovative projects of Organized Sections see www.apsanet.org/about/sections/ and click on the desired Section. 
year, Annual Meeting attendees will be able to check their email at the Cyber Stop. Most important is the project, led by William Ball of the College of New Jersey in concert with the Harvard Library and APSA, known as PROceedings, a searchable online archive of the year's Annual Meeting papers. Funded by the Mellon Foundation, which also created and maintains JSTOR, this project will need to be self-supporting by 2001, a challenge currently being considered by two APSA committees and the PROceedings partners.

In 1998, President Kent Jennings appointed an Ad Hoc Committee on Technology led by Pippa Norris of Harvard University to provide guidance on the Association's electronic projects, especially our web site. APSANet now contains more than 5,000 pages of information for members and the interested public, and will be presented in its third generation in the fall. The Ad Hoc Committee has been providing advice on this relaunch and helping the Association develop such policy concerning the site as oversight, access, and content.

\section{Changes in the Academic and Funding Environment}

The academic environment in which political scientists work has changed and this must be recognized by their academic association. Some of the symptoms of this change include the rise of a business culture in campus bureaucracies, attacks on the tenure system, replacement of tenured positions with part-time and nontenure-track jobs, state legislative mandates to increase faculty's student-contact hours and to engage in more assessment of teaching and "productivity," declining enrollments in political science courses and fewer majors, little or no clerical help for faculty, pressure on resources for faculty development, higher expectations across most institutions for faculty to publish and to obtain grants and other forms of recognition, the sapping of available time to think seriously, and a tight job market.

\section{Protecting Faculty Time}

Taken together, these pressures on faculty, especially junior faculty, are enormous and create the need to act together to respond appropriately. APSA committees and Council have worked to protect faculty time in a variety of ways. We have begun scheduling fewer face-to-face meetings and interacting more frequently and quickly via email and conference calls. In the organization of the Annual Meeting, the clerical work of the all-volunteer Program Committee should be greatly reduced thanks to the changes described in the previous section. The Committee on Organized Sections, led by

Joseph McCormick of Howard University, is considering instituting a rule to limit the number of times a dissertation can be submitted for prizes and, thus, the number of times award committee volunteers must read it. Along similar lines, APSA has for some years enforced a moratorium on new awards, thus limiting the number of committees that must read books and dissertations to determine a winner. The Departmental Services Committee, led by Ron Peters of the University of Oklahoma, has reduced the number of surveys and forms departmental chairs must complete but, at the same time, committed the Association to a continuous data collection effort that will ensure we know a lot about the state of political sciencefrom enrollments over time to the availability of resources of all sorts. That same committee holds an annual conference for chairs during which major issues facing departments are discussed, including assessment, tenure and posttenure review, recruitment, and related matters. The Committee on Educa- tion and Professional Development, led by Charles Johnson of Texas A\&M, along with the Departmental Services Committee, has commissioned the development of a professional videotape that will be released in 2000 to encourage undergraduates to major in political science and that will be distributed to departments, career centers, and local television stations.

\section{Funding for Research}

APSA is also working aggressively to help political scientists secure external funding for their projects. As part of $P$ Sonline, the national office has begun publishing extensive information on the latest developments in Washington concerning federal funding

for social scientists. Called Washington Insider, this publication reflects APSA's increasing visibility as an actor in Washington. In addition, the national office has invested significant time in informing individual political scientists of Washington news affecting the support of our discipline. If you would like to be a part of one or more of our listservs and receive periodic reports from Washington, please contact Theresa Gubicza (tgubicza@apsanet.org) to have your name added to the lists.

We are also expanding our online listings of public and private funding sources for political science, including NSF, NEH, the Pew Charitable Trusts (which provides almost four times as much support to political science as does NSF), and APSA's Small Research Grants, to list a few. Already available on our web site are examples of proposals that have been funded by NSF. A main premise of APSA's very successful Centennial Campaign, led by Dale Rogers Marshall and Jack Peltason, is that political scientists increasingly need the kind of outside support 


\begin{tabular}{ll} 
TABLE 1 & \\
Annual Meeting \\
Registration, $1968-98$ \\
\hline 1968 & 3723 (Washington, DC) \\
1969 & 4142 (New York) \\
1970 & 2397 (Los Angeles) \\
1971 & 2732 (Chicago) \\
1972 & 3380 (Washington, DC) \\
1973 & 2312 (New Orleans) \\
1974 & 2773 (Chicago) \\
1975 & 2478 (San Francisco) \\
1976 & 2295 (Chicago) \\
1977 & 2624 (Washington, DC) \\
1978 & 2373 (New York) \\
1979 & 2687 (Washington, DC) \\
1980 & 2745 (Washington, DC) \\
1981 & 2887 (New York) \\
1982 & 2205 (Denver) \\
1983 & 2859 (Chicago) \\
1984 & 3391 (Washington, DC) \\
1985 & 2842 (New Orleans) \\
1986 & 3602 (Washington, DC) \\
1987 & 3524 (Chicago) \\
1988 & 4161 (Washington, DC) \\
1989 & 3496 (Atlanta) \\
1990 & 4505 (San Francisco) \\
1991 & 5179 (Washington, DC) \\
1992 & 4998 (Chicago) \\
1993 & 5635 (Washington, DC) \\
1994 & 5902 (New York) \\
1995 & 5559 (Chicago) \\
1996 & 6055 (San Francisco) \\
1997 & 6391 (Washington, DC) \\
1998 & 6633 (Boston) \\
\hline
\end{tabular}

and recognition that an APSA Centennial Grant will provide.

President Matthew Holden has taken a special interest in the need for external funding and, in particular, in support provided by NSF. In September 1998, the Council authorized President Holden to deputize an ad hoc committee to investigate the relationship between political science and NSF. Led by Frank Sorauf, the committee has been working this year to understand the place of our discipline at the foundation and to make recommendations that might increase support of political science research in the future.

\section{Addressing the Loss of Tenure-Track Jobs}

Following APSA's cosponsorship of a 1998 conference on the use of part-time faculty, the Council autho-

rized the Association's participation in the Coalition on the Academic

Workforce, which is composed of a score of scholarly societies working to improve the treatment of part-timers and to prevent the substitution of temporary positions for tenuretrack ones. The excellent data collec-

More than once I have been asked, "Why should I be forced to pay for something I don't want?" low and typically does not include fringe benefits such as health insurance, retirement, or paid leave.

By ourselves, political scientists will not change this situation. Our best hope is to join with other groups to press for reform, as we are doing through the Coalition on the Academic Workforce. by the Departmental Services Committee allow us to know precisely how well new political science $\mathrm{Ph}$.D.s are faring in placement each year.

While detailed information is available in the December 1998 issue of $P S$, the key point is that those with a Ph.D. in hand continue to get jobs at the same relatively high rate that their recent predecessors have. However, ABDs fare much less well today than previously, and about $40 \%$ of the jobs secured by Ph.D.s in the most recent placement class were temporary, full-time positions. These new scholars must reenter the job market immediately, a major disruption of their personal and professional lives that adds to the already onerous load of a junior faculty member. For those who secure part-time jobs, the pay is extremely

\section{A Generational Divide}

These observations on placement lead to a third reason for the swift pace of change within APSA and points directly to the need to comprehend and respond to the different opportunity structure that younger generations of political scientists are facing. Complicating their professional lives is the fact that today's political scientists are much more likely to be parts of dualcareer couples than in the past. Further, perhaps as a result of the different world new Ph.D.s face, younger cohorts tend to hold different attitudes from their older counterparts, especially regarding issues likely to affect the future of APSA and the services that APSA ought to be providing its members.
TABLE 2 Operating Budget Summary, FY 1985-99

\begin{tabular}{crrr}
\hline Year & \multicolumn{1}{c}{ Income } & Expenditures & Surplus \\
\hline $1984-85$ & $\$ 1,415,077$ & $\$ 1,353,334$ & $\$ 54,738$ \\
$1985-86$ & $1,505,224$ & $1,453,248$ & 51,976 \\
$1986-87$ & $1,585,000$ & $1,500,000$ & 85,307 \\
$1987-88$ & $1,637,637$ & $1,563,252$ & 74,385 \\
$1988-89$ & $1,847,151$ & $1,731,248$ & 115,903 \\
$1989-90$ & $1,891,773$ & $1,871,302$ & 20,471 \\
$1990-91$ & $2,158,118$ & $2,133,524$ & 24,594 \\
$1991-92$ & $2,256,647$ & $2,199,632$ & 74,804 \\
$1992-93$ & $2,290,313$ & $2,202,419$ & 87,894 \\
$1993-94$ & $2,574,436$ & $2,294,128$ & 280,308 \\
$1994-95$ & $2,734,375$ & $2,524,663$ & 209,712 \\
$1995-96$ & $2,822,154$ & $2,590,227$ & 231,927 \\
$1996-97$ & $2,979,845$ & $2,793,237$ & 186,607 \\
$1997-98$ & $3,068,237$ & $2,981,914$ & 86,323 \\
$1998-99^{*}$ & $3,250,000$ & $3,220,000$ & 30,000 \\
\hline
\end{tabular}

*Projected. 
TABLE 3

Market Value of APSA Funds, 1986-99

\begin{tabular}{lcc}
\hline Year* & $\begin{array}{c}\text { Trust and Development } \\
\text { and Centennial } \\
\text { Campaign Funds }\end{array}$ & $\begin{array}{c}\text { Congressional Fellowship } \\
\text { and Endowed } \\
\text { Awards Funds }\end{array}$ \\
\hline 1986 & $1,677,365$ & 304,105 \\
1987 & $1,811,794$ & 362,174 \\
1988 & $1,685,345$ & 382,268 \\
1989 & $1,643,552$ & 394,837 \\
1990 & $1,630,718$ & 419,021 \\
$1991 \dagger$ & $1,555,574$ & $5,452,252$ \\
1992 & $1,905,090$ & $6,188,105$ \\
1993 & $2,118,787$ & $6,847,760$ \\
1994 & $2,190,976$ & $7,218,462$ \\
1995 & $2,807,182$ & $7,774,290$ \\
1996 & $3,248,013$ & $9,442,658$ \\
1997 & $4,283,425$ & $10,624,573$ \\
1998 & $5,965,087$ & $12,656,326$ \\
1999 (projected) & $6,523,661$ & $14,145,166$ \\
\hline
\end{tabular}

* June 30 of each year.

†Figures for 1991-93 were restated to reflect a change in accounting practice.

One difference is that young scholars seem more willing to embrace new communications technology than do older scholars. Also different are the generations' reasons for joining a scholarly society.

Young people no longer assume that one joins APSA simply to support the profession, as many in my generation did. Instead, they are apt to ask, "What do I get for my time and money?" Relatedly, there seems to be less acceptance of "elders" making decisions concerning what comprises an appropriate membership package. More than once I have been asked, "Why should I be forced to pay for something I don't want?" Whether this attitude reflects the desire to makes one's own choices or an unwillingness to pay for public goods, or both, its emergence will have a profound impact on the future of this association.

\section{Preparation for What?}

Another important generational difference, reflecting the changed world for which the emerging generation is preparing, is the fact that most new Ph.D.s will not find jobs in Ph.D.-granting institutions, even though many graduate institutions insistently train their students as if they will. This results, of course, in feelings of failure and disappointment when newly hired doctorates find themselves inadequately prepared for the positions they have assumed. APSA's Academic Administrators Group, an informal collection of political scientists in highlevel administrative positions, have expressed dismay with graduate training that does not prepare students for teaching undergraduates, thinking comprehensively across fields, and serving their institutions.

New Ph.D.s need to be prepared for the jobs they are most likely to obtain not only as college faculty but also as applied political scientists in nonfaculty jobs. Dual-career couples find it increasingly necessary for one member to accept a nonfaculty job so the other member can take a tenure-track position. Moreover, as tenure-track positions hold steady or decline, political scientists will need to be prepared to exercise their skills beyond the walls of academe, especially if graduate programs persist in increasing the number of Ph.D.s they graduate each year. (Between 1987 and 1997, the annual number of $\mathrm{Ph}$.D.s produced in political science increased by $50 \%$.)
TABLE 4

Organized Section

Members, 1999

\begin{tabular}{|c|c|c|}
\hline & Organized Section & $\begin{array}{c}\text { Number } \\
\text { of } \\
\text { Members* }\end{array}$ \\
\hline 1 & $\begin{array}{l}\text { Federalism and } \\
\text { Intergovernmental } \\
\text { Relations }\end{array}$ & 378 \\
\hline 2 & Law and Courts & 750 \\
\hline 3 & Legislative Studies & 622 \\
\hline 4 & Public Policy & 792 \\
\hline 5 & $\begin{array}{l}\text { Political Organizations } \\
\text { and Parties }\end{array}$ & 568 \\
\hline 6 & Public Administration & 576 \\
\hline 7 & Conflict Processes & 301 \\
\hline 8 & $\begin{array}{l}\text { Representation and } \\
\text { Electoral Systems }\end{array}$ & 350 \\
\hline 9 & Presidency Research & 394 \\
\hline 10 & Political Methodology & 663 \\
\hline 11 & Religion and Politics & 473 \\
\hline 13 & Urban Politics & 383 \\
\hline 15 & $\begin{array}{l}\text { Science, Technology, } \\
\text { and Environmental } \\
\text { Policy }\end{array}$ & 319 \\
\hline 16 & Women and Politics & 581 \\
\hline 17 & $\begin{array}{l}\text { Foundations of } \\
\text { Political Theory }\end{array}$ & 581 \\
\hline 18 & $\begin{array}{l}\text { Computers and } \\
\text { Multimedia }\end{array}$ & 224 \\
\hline 19 & $\begin{array}{l}\text { International Security } \\
\text { and Arms Control }\end{array}$ & 437 \\
\hline 20 & Comparative Politics & 1431 \\
\hline 21 & $\begin{array}{l}\text { Politics and Society } \\
\text { in Western Europe }\end{array}$ & 388 \\
\hline 22 & $\begin{array}{l}\text { State Politics and } \\
\text { Policy }\end{array}$ & 385 \\
\hline 23 & $\begin{array}{l}\text { Political } \\
\text { Communication }\end{array}$ & 406 \\
\hline 24 & Politics and History & 595 \\
\hline 25 & Political Economy & 596 \\
\hline 26 & $\begin{array}{l}\text { Transformational } \\
\text { Politics }\end{array}$ & 228 \\
\hline 27 & New Political Science & 309 \\
\hline 28 & Political Psychology & 341 \\
\hline 29 & $\begin{array}{l}\text { Undergraduate } \\
\text { Education }\end{array}$ & 347 \\
\hline 30 & Politics and Literature & 240 \\
\hline 31 & $\begin{array}{l}\text { Public Opinion and } \\
\text { Foreign Policy }\end{array}$ & 267 \\
\hline 32 & $\begin{array}{l}\text { Elections, Public } \\
\text { Opinion, and Voting } \\
\text { Behavior }\end{array}$ & 684 \\
\hline 33 & $\begin{array}{l}\text { Race, Ethnicity \& } \\
\text { Politics }\end{array}$ & 446 \\
\hline
\end{tabular}


TABLE 5

APSA Members 1974-99

\begin{tabular}{|c|c|c|c|c|c|c|c|c|c|}
\hline Year* & Regular & Associate & Unemployed & Retired & Life & Family & Student & $\begin{array}{c}\text { Total } \\
\text { Individual }\end{array}$ & $\begin{array}{c}\text { Total } \\
\text { Institutional }\end{array}$ \\
\hline 1974 & 7,793 & & & 217 & 101 & 137 & 4,006 & 12,254 & 3,504 \\
\hline 1975 & 7,335 & & & 206 & 100 & 149 & 3,912 & 11,702 & 3,648 \\
\hline 1976 & 7,428 & & & 245 & 96 & 134 & 3,603 & 11,506 & 3,588 \\
\hline 1977 & 7,228 & & & 270 & 95 & 142 & 3,076 & 10,811 & 3,466 \\
\hline 1978 & 7,094 & & & 301 & 97 & 154 & 2,655 & 10,301 & 3,338 \\
\hline 1979 & 6,845 & & & 310 & 91 & 148 & 2,335 & 9,729 & 3,339 \\
\hline 1980 & 6,592 & & & 344 & 91 & 135 & 2,159 & 9,321 & 3,337 \\
\hline 1981 & 6,423 & & & 349 & 92 & 129 & 1,901 & 8,894 & 3,283 \\
\hline 1982 & 5,838 & & & 388 & 97 & 134 & 1,984 & 8,441 & 3,156 \\
\hline 1983 & 5,764 & & & 382 & 104 & 130 & 2,068 & 8,448 & 3,018 \\
\hline 1984 & 5,891 & & & 378 & 111 & 151 & 2,511 & 9,042 & 3,059 \\
\hline 1985 & 5,879 & 106 & & 411 & 116 & 166 & 2,595 & 9,273 & 2,996 \\
\hline 1986 & 6,009 & 145 & & 432 & 117 & 173 & 2,589 & 9,465 & 3,046 \\
\hline 1987 & 5,913 & 154 & & 439 & 127 & 202 & 2,775 & 9,610 & 3,109 \\
\hline 1988 & 6,171 & 173 & & 450 & 129 & 186 & 2,728 & 9,837 & 2,975 \\
\hline 1989 & 6,445 & 249 & & 489 & 166 & 192 & 3,054 & 10,595 & 2,948 \\
\hline 1990 & 6,708 & 258 & & 488 & 163 & 180 & 3,436 & 11,233 & 3,004 \\
\hline 1991 & 6,967 & 266 & & 519 & 160 & 199 & 3,656 & 11,767 & 2,890 \\
\hline 1992 & 7,046 & 279 & & 557 & 159 & 182 & 3,740 & 11,963 & 3,057 \\
\hline 1993 & 7,061 & 291 & & 573 & 157 & 194 & 3,979 & 12,255 & 2,887 \\
\hline 1994 & 7,505 & 343 & & 593 & 159 & 195 & 4,121 & 12,916 & 2,908 \\
\hline 1995 & 7,654 & 340 & & 623 & 164 & 205 & 4,750 & 13,736 & 2,812 \\
\hline 1996 & 7,349 & 323 & & 596 & 168 & 210 & 4,618 & 13,264 & 2,841 \\
\hline 1997 & 7,808 & 429 & 82 & 625 & 167 & 218 & 4,611 & 13,940 & 2,706 \\
\hline 1998 & 7,464 & 400 & 226 & 607 & 165 & 206 & 4,319 & 13,387 & 2,653 \\
\hline 1999 & 8,873 & 395 & 246 & 600 & 161 & 186 & 3,817 & 12,690 & 2,331 \\
\hline
\end{tabular}

\section{Responding to the Needs of New Ph.D.s}

What is APSA doing to respond to the needs of senior graduate students and newly graduated political scientists? First, with the help of the graduate programs, we are systematically collecting data on placement to give us a good sense of how well the profession absorbs new Ph.D.s, and we are widely distributing the results. Second, three digital projects have been undertaken to facilitate placementE-jobs, PSonline, and the APSAECPR Scholar Clearinghouse, all discussed above. Third, we are conducting an all-out assault to discover and advertise nonfaculty jobs for which political scientists might be eligible and we are publishing a monograph, scheduled to appear at the first of the year, on academic and applied careers in political science. Fourth, using the tools at our disposal, like $P S$, its digital relative PSonline, and the Annual Conference for Chairs, we are publicizing the concerns articulated here so that actions can be taken by graduate programs and students.

Fifth, APSA's officers and Council host a large welcoming reception for graduate students at the Annual Meeting and accept gladly their participation in all parts of APSA ranging from publishing in $A P S R$ to delivering papers at the Annual Meeting. APSA even provides financial support for selected students presenting papers at the conference. Sixth, the national office is constructing a new professional opportunities section for our web site, which will appear in the fall. This page will accompany the existing ones on funding opportunities and other information on research support.

Seventh, the Education and Professional Development Committee is continuing to bring out syllabi collections to help new faculty, in particular, think seriously about their teaching and prepare for new courses. Eighth, our new teaching web site, maintained with the assistance of Contributing Editor Stephen Bennett of the University of Cincinnati, and each issue of $P S$ contain much of use to rookies and veterans, especially those with a breadth of undergraduate teaching assignments. Ninth, APSA celebrates political scientists who win campus 


\section{APSA Membership}

$1974-1999$

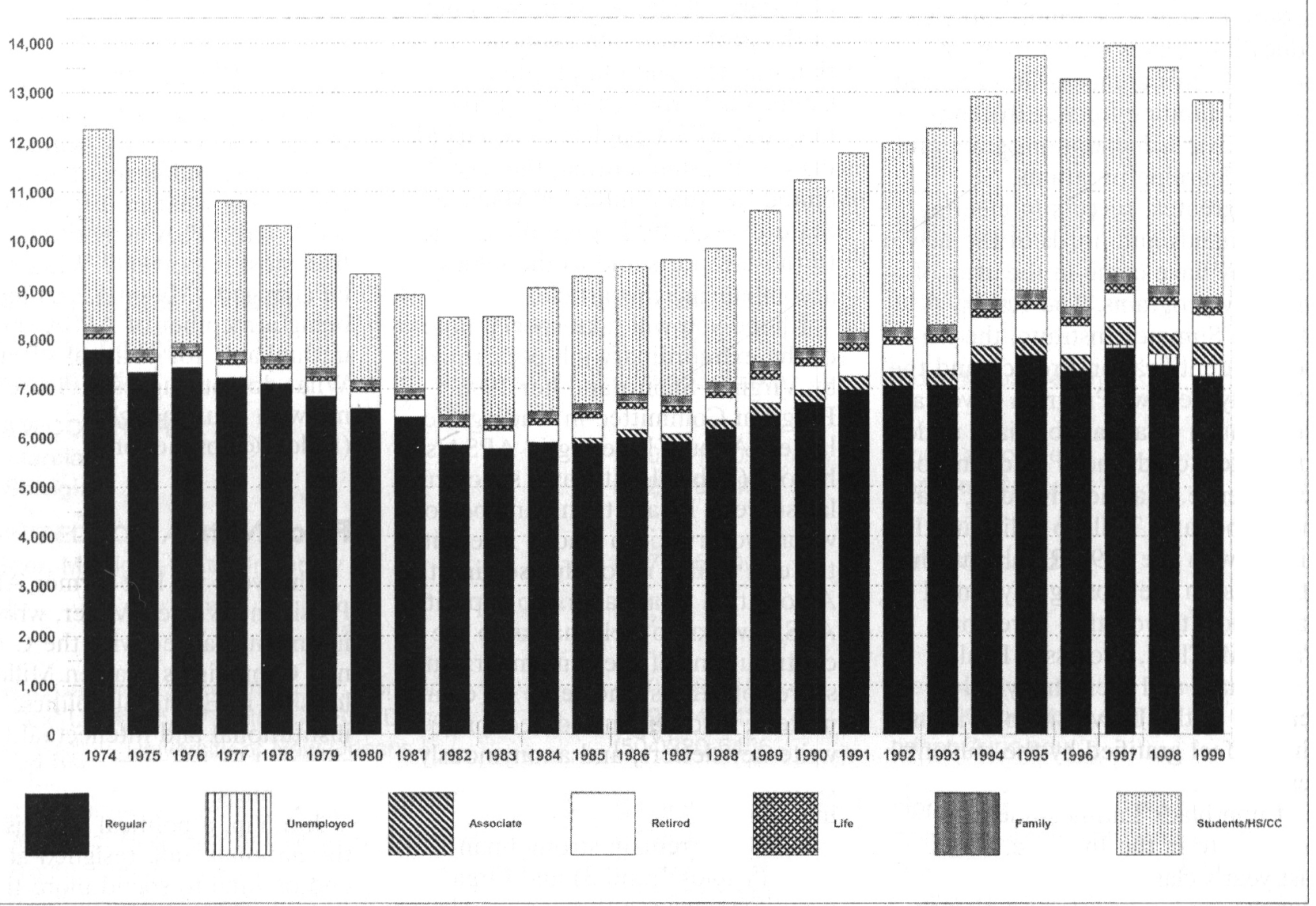

awards for outstanding teaching at a special Honors Reception, in the Annual Meeting Program, and in PS.

And, tenth, realizing that they have been beneficiaries of a "golden age in higher education," the members of APSA are generously contributing to the programs of the Centennial Campaign that will provide significant opportunities for upcoming generations of political scientists. No other scholarly society of which I am aware has so many members giving so magnanimously to support the work of their successors.

\section{What Are Our Societal Responsibilities?}

APSA is also changing because political scientists have responsibilities in the larger society. Through the Task Force on Civic Education for the Next Century, established in 1997 under Elinor Ostrom's presidency, political scientists are being called on to address such problems as the decline of trust in government, the poor preparation of students in $\mathrm{K}-12$ to participate in civic life, getting college students involved and engaged through political science courses and internship programs, and encouraging the development of civic values and academic political science in new democracies. Renewed calls to address these issues are now being joined by demands that the academy be more interdisciplinary and racially diverse.
Reaching Out

These are areas where APSA has made some inroads. We offer interdisciplinary memberships with three other scholarly societies, consult a group of area studies scholars to ensure that area studies is well represented in APSA

programs like the Annual Meeting, and share our journals with approximately 40 Subsaharan African and Eastern European university libraries in emerging democracies. Moreover, the Association is reaching out to community college and high school teachers in a variety of ways: inexpensive memberships, departmental services program for these 
two groups, and special invitations and rates to attend the Annual Meeting. APSA Director of Education and Professional Development Sheilah Mann has taken a national leadership role on behalf of the profession in service learning and civic education, serves on a variety of boards in this area, and has secured external funding for our International Civic Education program and service learning programs.

Our greatest success in meeting the demands and needs of the new academy have come in the area of minority programs. The Ralph Bunche Summer Institute, the Minority Identification Project, and the Minority Fellows Program have each done much to attract brilliant undergraduates to advanced study in political science. Matthew Holden, Maurice Woodard, Titilayo Ellis, and I visited with the 1999 Ralph Bunche students on the closing day, and I can report to you that Director Paula McClain, Professor Paul Freedman, and their many colleagues at the University of Virginia should feel gratified by the students' testimonials, including that of the first non-black Latina student to participate in the Institute. From last year's class, a record seven Bunche students are going directly to graduate school with full funding. That record should be broken this year.

While we political scientists cannot afford to turn our backs on our societal responsibilities, we must determine the weight we wish to place on addressing them in our already too-demanding professional lives. The tendency, of course, is to want to leave these matters to someone else. After all, what do we know about K-12 education? Because we help instruct the K-12 teachers, it is our obligation to be sure that they are well-prepared for their tasks. Further, as we have learned in the area of minority recruitment, if we do not take up these challenges, the world that we hope for will not materialize.

\section{Vital Signs and Strategic Planning}

Much of what we have done together this year is going unreported in this account. However, the pages of $P S$ are filled each issue with news of the profession and Association-on new and old programs, Council actions, committee activities, and APSA publications, including our flagship journal, the $A P S R$, edited by Ada Finifter of Michigan State University. Let me direct you to those reports and to the tables accompanying this article.

I hope you will take special note of the extraordinary job performed by Virginia Sapiro and her 1998 Program Committee in leading the largest Annual Meeting in APSA's history (Table 1). It was a spectacular success. Please thank any person whom you run into who is listed at the end of this report for serving the Association in a leadership capacity. APSA works so well thanks to the contributions of these members and scores of others who serve on committees, lead Organized Sections, write newsletters, and anonymously review manuscripts for our outstanding journals.

While we remain strong financially (Tables 2 and 3 ) and Organized Sections are thriving (Table 4), you should note that membership has declined for the second year in a row (Table 5 and Figure 1). The decline in membership last year led the national office to conduct two mail surveys, one for members and one for former members. While the response rates were not what we might have wanted, the results were suggestive and parallel some of the matters I discussed above in the section on the generational divide. The combination of declining membership numbers, the critical survey results, increasingly tight operational budgets, the opportunities (and perils) associated with digital technology, and the desire to extend APSA's welcome to political scientists around the world has led President Holden, President-Elect Robert O. Keohane, the Council, and the national office to believe that now is the time to engage in some strategic planning. Preliminary steps have already been taken and a committee will be appointed in the fall to draft a strategic plan.

\section{Help Us Set Priorities}

As the planning for the Association's second century begins, we need ideas and suggestions from you concerning what priorities should be set. What APSA activities do you find most important? What needs to be changed? My goal is to make not being a member of APSA simply unthinkable for political scientists. What do you suggest? Please email me with your thoughts (rudder@apsanet.org).

\section{Final Notes}

This year we lost former APSA President Warren Miller, who is being memorialized with the Centennial Campaign's Warren Miller Fellowship in Electoral Politics. His institutional and intellectual leadership will be sorely missed by all in this profession.

Jun Yin, a politicai scientist on the national staff, resigned at the end of June to spend more time with her family. I know many of you have enjoyed the privilege of working with her as much as I and join me in wishing her well in her career.

Finally, the Administrative Committee has granted me a sabbatical leave of six months beginning in late September. I have been awarded a two-month Public Policy Fellowship at the American Academy in Berlin and am grateful to the American Academy and to the Bosch Foundation for this wonderful opportunity to study German philanthropy. Upon my return, I plan to work on some of the broader issues affecting the future of scholarly societies and hope that the result will be of use to APSA's strategic planning effort. Deputy Director Robert Hauck has graciously agreed to serve as acting executive director in my absence.

July 13, 1999 
APSA Officers-1998-99

\section{PRESIDENT}

Matthew Holden Jr., University of Virginia

PRESIDENT-ELECT

Robert O. Keohane

VICE PRESIDENTS

Jean Bethke Elshtain, University of Chicago

Germaine A. Hoston, University of California, San Diego

Paul Sniderman, Stanford University

TREASURER

Timothy Cook, Williams College

Kay L. Schlozman, Boston College

EXECUTIVE DIRECTOR

Catherine E. Rudder

PROGRAM CO-CHAIRS

John A. Garcia

Alberta Sbragia

MANAGING EDITOR, APSR

Ada Finifter, Michigan State University

\section{COUNCIL}

1997-99

Jane Bayes, California State University, Northridge

Gary W. Cox, University of California, San Diego

Charles D. Hadley, University of New Orleans

Kristen R. Monroe, University of California, Irvine

Pippa Norris, Harvard University

Beth A. Simmons, University of California, Berkeley

Joan C. Tronto, Hunter College

Michael Wallerstein, Northwestern University

1998-00

Michael Dawson, University of Chicago

Luis Fraga, Stanford University

Cynthia McClintock, George Washington University

Eileen L. McDonagh, Northeastern University

Nancy E. McGlen, Niagara University

Howard J. Silver, Consortium of Social Science Associations

James A. Stimson, University of North Carolina

J. Ann Tickner, University of Southern California

\section{Officer Nominees}

1999-00

Robert Jervis, Columbia University

Guillermo O'Donnell, University of Notre Dame

Virginia Sapiro, University of Wisconsin-Madison

Roberta Sigel, Rutgers University

Fritz Scharpf, Max Planck Institute, Cologne

James Stimson, University of North Carolina

\section{Council Nominees}

1999-01

Randall Calvert, University of Rochester

William Galston, University of Maryland

Edmond Keller, University of California, Los Angeles

Gary King, Harvard University

Atul Kohli, Princeton University
(413)597-2168

$(617) 552-4174$

Telephone

Numbers

(804)924-3422

$(919) 660-4322$

(773)702-7252

(619)538-5483

(617)552-4174

(202)483-2512

(520)621-7095

(412)648-7405

(517)355-3400

(310)459-7151

(619)534-1428

(504)280-6456

(714)824-6092

(617)495-1475

(510)642-6323

(212) $772-5681$

(847)491-2646

(312)702-8462

(650)723-5319

(202)994-6589

(617) $373-4403$

(716)286-8059

(202)842-3525

(919)962-0428

(213)740-2266

(212) $854-4610$

(219)631-7756

(608)263-2024

(609)466-1626

492213360512

(919)962-0428

(716)275-7252

(301)405-6347

(310)825-2566

(617)495-2027

(609)258-6408
Email Addresses

mh3q@virginia.edu

rkeohane@acpub.duke.edu

lawr@midway.uchicago.edu

ghoston@uscd.edu

paulms@leland.stanford.edu

timothy.e.cook@williams.edu

kschloz@bcvms.bc.edu

rudder@apsanet.org

jag@u.arizona.edu

sbragia+@pitt.edu

finifter@msu.edu

jbayes@csun.edu gcox@weber.ucsd.edu cdhpo@uno.edu krmonroe@orion.uci.edu pippa_norris@harvard.edu bsimmons@socrates.berkeley.edu jtronto@shiva.hunter.cuny.edu m-wallerstein@nwu.edu

mc-dawson@uchicago.edu fraga@stanford.edu mcclin@gwu.edu emcd@neu.edu nmcglen@niagara.edu silverhj@erols.com jstimson@email.unc.edu tickner@bcf.usc.edu

rlj1@columbia.edu guillermo.a.odonnell.|@nd.edu sapiro@polisci.wisc.edu

scharpf@mpi-fg-koeln.mpg.de jstimson@email.unc.edu

rcal@troi.cc.rochester.edu wg14@umail.umd.edu ekeller@ucla.edu king@harvard.edu kohli@wwws.princeton.edu 
George Marcus, Williams College

David Rayside, University of Toronto

Christine Marie Sierra, University of New Mexico

Sven Steinmo, University of Colorado, Boulder

\section{STANDING COMMITTEE CHAIRS}

\section{Nominating Committee}

Dianne Pinderhughes, University of Illinois, UrbanaChampaign

Trust and Development Board of Trustees

Timothy Cook, Williams College, APSA Treasurer

Committee on Departmental Services

Ronald Peters, University of Oklahoma

Committee on Publications

Bert Rockman, University of Pittsburgh

Committee on Education \& Professional Development

Charles Johnson, Texas A\&M University

Committee on International Political Science

Richard Merritt, University of Illinois, Urbana-Champaign

Committee on Professional Ethics, Rights and Freedoms

Matthew Moen, University of Maine

Research Support Advisory Committee

Russell Neuman, University of Pennsylvania

Committee on the Status of Blacks in the Profession Edward R. Jackson, Southern University

Committee on the Status of Latinos in the Profession Gregory Rocha, University of Texas, EI Paso

Committee on the Status of Women in the Profession Molly L. Shanley, Vassar College

Endowed Programs Committee

Linda Fowler, Dartmouth College

Committee on the Status of Lesbians and Gays in the Profession

Shane Phelan, University of New Mexixo

Committee on Organized Sections

Joseph McCormick, Howard University

Editorial Board, $P S$

Richard Brody, Stanford University

Ad Hoc Task Force on Civic Education for the Next Century

Melvin J. Dubnik, Rutgers University

Jean Bethke Elshtain, University of Chicago

\section{CENTENNIAL CAMPAIGN}

\section{Co-Chairs}

Dale Rogers Marshall, Wheaton College

Jack Peltason, University of California

Executive Committee Co-Chairs

Frank Sorauf, University of Minnesota

Roger Davidson, University of Maryland
(505)277-5104

(202)806-6722

(413)597-2538

(416)978-8087

(505)277-1098

(303)492-1493

(217)333-3880

(413)597-2537

(405)325-6372

(412)648-7287

$(409) 845-8833$

(217)344-4573

(207)581-1885

(215)898-6195

(504)771-3210

(915)747-7977

(914)437-5562

(603)646-3874

(415)723-0672

(978)921-5922

(312)702-7252

(508)285-8244

(714)824-3938

(612)624-5503

(301)405-4113 george.e.marcus@williams.edu david.rayside@utoronto.ca csierra@unm.edu steinmo@colorado.edu

dpinderh@uiuc.edu

timothy.e.cook@williams.edu

rpeters@uoknor.edu

brockman+@pitt.edu

e33cj@polisci.tamu.edu

richmerr@uiuc.edu

moen@maine.maine.edu

rneuman@pobox.asc.upenn.edu

grocha@utep.edu

shanley@vassar.edu

linda.fowler@dartmouth.edu

sphelan@carina.unm.edu

jmccormick@fac.howard.edu

brody@leland.stanford.edu

dubnick@mediaone.net lawr@midway.uchicago.edu

dmarshall@wheatonma.edu newbean@aol.com

sorauf@polisci.umn.edu rdavidso@bss2.umd.edu 
Presidents Council Co-Chairs

Lucius Barker, Stanford University

Elinor Ostrom, Indiana University

Finance Co-Chairs

Susan Bourque, Smith College

Loren Ross, Cedarpoint Capital Management of New York

Minority Identification Project Steering Committee

Elliott Slotnick, Ohio State University

Congressional Fellowship Program Advisory

Committee

Norman Ornstein, American Enterprise Institute for Public Policy

\section{APSA Representatives to Affiliated Organizations}

American Association for the Advancement of Science (AAAS)-Section $\mathrm{K}$

Gary King, Harvard University

American Association for the Advancement of Slavic Studies (AAASS)

Carol Nechemias, Pennsylvania State University, Harrisburg

American Council of Learned Societies (ACLS)

Ronald Kahn, Oberlin College

Consortium of Social Science Associations (COSSA)

Clyde Wilcox, Georgetown University

Catherine E. Rudder, APSA

International Political Science Association (IPSA)

Theordore J. Lowi, Cornell University

Paula D. McClain, University of Virginia

Catherine E. Rudder, APSA

Social Science Research Council

Sidney Verba, Harvard University

National Archives and Records Administration

Martha J. Kumar, Towson State University

National Coordinating Committee for the Promotion of History

Martha J. Kumar, Towson State University

U.S. Department of State Advisory Committee on Historical Diplomatic Documentation

Vincent Davis, University of Kentucky

APSA Political Science Staff

Robert J-P. Hauck, Deputy Director

Sheilah Mann, Director of Educational Programs

Maurice Woodard, Director of Minority Affairs

APSA Annual Meeting Manager

Jennifer Richards

APSA Business Office Manager

Laura Tyson
(410)328-9498

mkumar@towson.edu

(415)723-0408

(812)855-3151

(413)585-3000

(212)308-9081

$(614) 292-2880$

(202)862-5893

$(617) 495-2027$

(717)948-6049

$(404) 775-8495$

(202)686-5273

(202) $483-2512$

$(607) 255-6205$

(804) $924-3614$

(202)483-2512

(617)495-3650

(410)328-9498

(606)257-4666

vdavis@ukcc.uky.edu

rhauck@apsanet.org

smann@apsanet.org

woodard@apsanet.org

jrichards@apsanet.org

Ityson@apsanet.org 